\title{
Case Report Spectrum of Surgical Presentation of Eosinophilic Enteritis
}

\author{
Spoorthy Sudhakar Shetty ${ }^{1}$ and Charan Kishor Shetty ${ }^{2}$ \\ ${ }^{1}$ Department of Surgery, Faculty of Medicine and Health Sciences, UCSI University, Bukit Kor, PT 11065, Mukim Rusila, \\ 21600 Marang, Terengganu, Malaysia \\ ${ }^{2}$ Department of Forensic Medicine, Faculty of Medicine, Universiti Sultan Zainal Abidin (Unisza), Kampus Kota, \\ Jalan Sultan Mahmud, 20400 Kuala Terengganu, Terengganu, Malaysia \\ Correspondence should be addressed to Spoorthy Sudhakar Shetty; inspirespoo@yahoo.com
}

Received 22 February 2015; Revised 30 March 2015; Accepted 7 April 2015

Academic Editor: Riccardo Nascimbeni

Copyright @ 2015 S. S. Shetty and C. K. Shetty. This is an open access article distributed under the Creative Commons Attribution License, which permits unrestricted use, distribution, and reproduction in any medium, provided the original work is properly cited.

Eosinophilic enteritis is a rare disorder presenting mostly with diarrhea, malabsorption, abdominal pain, weight loss, and hypersensitivity. Surgical manifestation of eosinophilic gastrointestinal disorders depends on the site and extent of involvement. In our case series of four patients two of them had ileocaecal masses with recurrent subacute intestinal obstruction with past history of intake of antitubercular drugs for 9 months. On histopathological examination both of them proved to have eosinophilic enterocolitis. Thus it is a clinical dilemma to differentiate between these two conditions. The other two patients presented as acute abdomen with perforation and intussusception. All four patients were treated surgically. Postoperatively they recovered well with no symptoms on one year follow-up. In Indian setup tuberculosis being rampant there may be under reporting or wrongly diagnosed cases of eosinophilic enteritis. Thus a strong clinical suspicion and awareness of this clinical entity are essential among surgical community.

\section{Introduction}

Eosinophilic enteritis is a rare disorder presenting mostly with diarrhea, malabsorption, abdominal pain, weight loss, and hypersensitivity. Surgical manifestation of eosinophilic gastrointestinal disorders depends on the site and extent of involvement. Accordingly they can be divided as eosinophilic esophagitis, eosinophilic enteritis, eosinophilic gastritis, and eosinophilic colitis. Eosinophilic gastrointestinal disorders can be primary or secondary to helminthic, fungi, hypereosinophilic syndrome (HES), systemic disease (e.g., connective tissue disease, vasculitis, celiac disease, and inflammatory bowel disease), and drugs (e.g., naproxen, clozapine, rifampicin, and gold) [1]. Presentation tends to be dependent on which intestinal layer is most affected by the eosinophilic infiltration. Mucosa predominant disorder is associated with mucosal injury and presents with malabsorption, diarrhoea, and protein-losing enteropathy. Transmural disease presents with colonic wall thickening and features of intestinal obstruction. Eosinophilic predominant ascites is a manifestation of serosal involvement. Eosinophilic colitis can present acutely with abdominal symptoms such as caecal volvulus causing intestinal obstruction, intussusception, and perforation [2]. Treatment of eosinophilic enterocolitis is antihistamines, mast cell stabilizers, glucocorticosteroids, and immunosuppressive agents along with surgery for acute surgical emergencies.

In Indian scenario where abdominal tuberculosis is widely prevalent, eosinophilic enterocolitis is under reported. Eosinophilic colitis mimics abdominal tuberculosis with identical symptoms of fever, weight loss, abdominal pain, recurrent subacute intestinal obstruction, and ascites. CT scan also has a similar picture of pulled up caecum, strictures, and ascites especially in transmural type of enterocolitis.

\section{Case Presentation}

Case 1. A 57-year-old male with features of recurrent subacute intestinal obstruction from past one year was evaluated with ultrasonography which showed multiple dilated bowel 


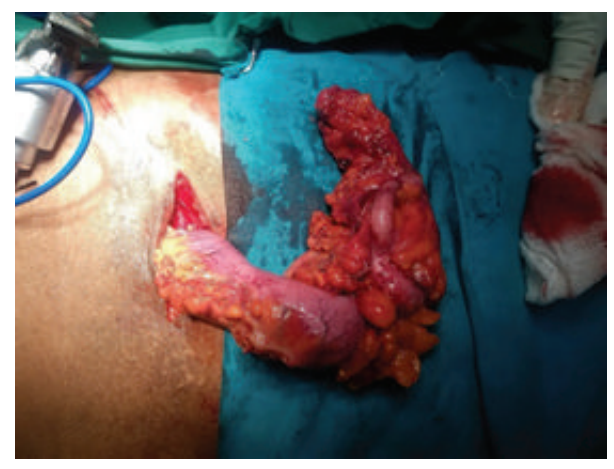

Figure 1: Ileocaecal mass specimen after laparoscopic hemi colectomy (case 1).

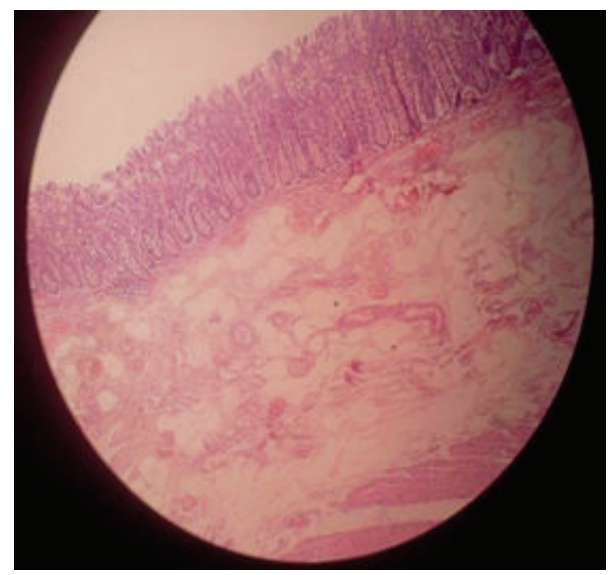

FIGURE 2: Infiltration of eosinophils is seen in all layers of intestine with large number of intraepithelial eosinophils and eosinophilic micro abscess.

loops with sluggish peristalsis. We suspected tuberculosis of abdomen as patient gave history of intake of antitubercular drugs for 9 months 1 year back. Patient contrast enhanced CT scan showed thickening in the ileocaecal area with mesenteric lymphadenopathy and dilated bowel loops. Patient had an elevated ESR and lymphocytosis. Patient had diagnostic laparoscopy which showed a pulled up and thickened shrunken caecum along with an ileal stricture. He underwent a right laparoscopic hemicolectomy procedure (Figures 1 and 2). Postoperatively patient recovered well. On histopathological examination of specimen eosinophilic infiltration was seen in all layers of intestine. Patient's absolute eosinophilic count was $550 /$ cumm.

Case 2. A 32-year-old male patient came to emergency surgical department with acute abdominal pain. On examination patient had tachycardia with blood pressure of $100 / 60 \mathrm{~mm} \mathrm{Hg}$ with high colored urine. Abdominal examination revealed generalized tenderness, guarding, and rigidity. Patients abdominal X-ray erect showed air under diaphragm. Patient underwent an exploratory laparotomy in view of features suggestive of perforative peritonitis. Patient had perforation of ileum with two distal ileal stricture and fibrosed

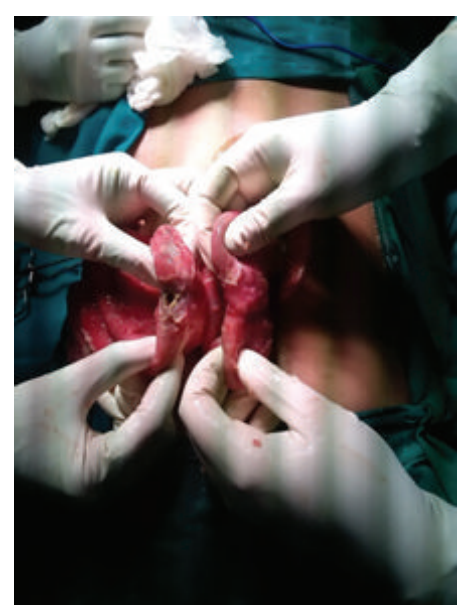

FIGURE 3: Ileal perforation with stricture (Case 2).

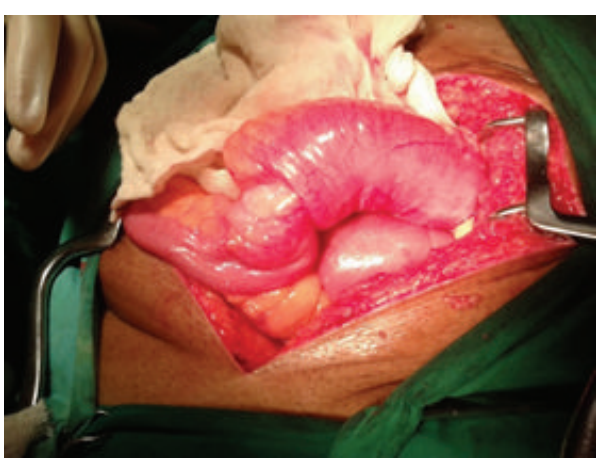

FIGURE 4: Ileoileal intussusception in a case of eosinophilic enteritis (Case 3).

caecum. Ileotransverse bypass was done with closure of ileal perforation after taking biopsy (Figure 3). Postoperatively after histopathological examination patient had eosinophilic enteritis. Patient was given a course of steroid and antihelminthic drugs. Postoperative course was uneventful. We gave steroid in the second patient because we had not done any resective procedure in this patient. We only took multiple biopsies from perforated area and did ileotransverse bypass procedure and left the affected bowel as patient presented in septic shock.

Case 3. A 24-year-old male came with history of constipation, recurrent vomiting, and abdominal distention since 1 day. On evaluation patient had tachycardia with low blood pressure. Patient's abdominal X-ray showed multiple air fluid level and CT scan showed intestinal obstruction with target sign suggestive of intussusception. Exploratory laparotomy was done which showed dilated bowel loops with ileoileal intussusception at the level of distal ileum (Figure 4). Resection anastomosis was performed. Specimen analysis showed eosinophilic enteritis. Patient had elevated absolute eosinophilic count. On one year follow-up patient was symptom-free. 
TABLE 1: Clinical manifestation, ultrasound findings, and clinical diagnosis.

\begin{tabular}{|c|c|c|c|c|c|}
\hline Number & Age/sex & Symptoms/drug history & Radiological finding & Clinical diagnosis & Laboratory findings \\
\hline 1 & $57 / \mathrm{M}$ & $\begin{array}{l}\text { Recurrent constipation } \\
\text { Vomiting and distention } \\
\text { on and off } 1 \text { year } \\
\text { Antitubercular drugs for } \\
9 \text { months [CAT 1] }\end{array}$ & $\begin{array}{l}\text { CECT: thickening in } \\
\text { ileocaecal area with } \\
\text { mesenteric } \\
\text { lymphadenopathy with } \\
\text { dilated loops }\end{array}$ & $\begin{array}{l}\text { Recurrent intestinal } \\
\text { obstruction }\end{array}$ & $\begin{array}{l}\text { ESR: } 108 \\
\text { AEC: } 550 / C u m m \\
\text { Chest X ray: } \\
\text { Signs of fibrosis healed } \\
\text { tuberculosis } \\
\text { Stool examination: NAD } \\
\text { Montoux test: negative }\end{array}$ \\
\hline 2 & $32 / \mathrm{M}$ & $\begin{array}{l}\text { Acute abdomen } \\
\text { Guarding } \\
\text { Rigidity } \\
\text { Tachycardia } \\
\text { Hypotension } \\
\text { No h/o of chronic } \\
\text { medication } \\
\end{array}$ & $\begin{array}{l}\text { X-ray erect } \\
\text { chest/abdomen showed } \\
\text { air under diaphragm }\end{array}$ & $\begin{array}{l}\text { Acute perforative } \\
\text { peritonitis }\end{array}$ & $\begin{array}{l}\text { ESR: } 100 \\
\text { AEC: } 320 \text { cells/cum } \\
\text { Chest X-ray: NAD } \\
\text { Stool examination: NAD } \\
\text { Montoux test: negative }\end{array}$ \\
\hline 3 & $24 / \mathrm{M}$ & $\begin{array}{l}\text { Obstipation, vomiting, } \\
\text { and abdominal } \\
\text { distention since } 1 \text { day } \\
\text { No h/o chronic } \\
\text { medication }\end{array}$ & $\begin{array}{l}\text { X-ray abdomen: } \\
\text { multiple air fluid level } \\
\text { CECT abdomen: target } \\
\text { sign suggestive of } \\
\text { intussusception with } \\
\text { obstruction }\end{array}$ & $\begin{array}{l}\text { Acute intestinal } \\
\text { obstruction due to } \\
\text { ileo ileal } \\
\text { intussusception }\end{array}$ & $\begin{array}{l}\text { ESR: } 25 \\
\text { AEC: } 600 \text { cells/cumm } \\
\text { Chest X-ray: NAD } \\
\text { Stool examination: NAD } \\
\text { Montoux test: negative }\end{array}$ \\
\hline 4 & $62 / \mathrm{M}$ & $\begin{array}{l}\text { Constipation, abdominal } \\
\text { distention, and vomiting } \\
\text { on and off since past } 3 \\
\text { months } \\
\text { h/o intake of } \\
\text { amlodipine, aspirin, and } \\
\text { atorvastatin for } 20 \text { years } \\
\text { Antitubercular } \\
\text { treatment } 35 \text { years back }\end{array}$ & $\begin{array}{l}\text { USG: Multiple dilated } \\
\text { loops with sluggish } \\
\text { peristalsis } \\
\text { CECT: thickening in ileo } \\
\text { caecal area with } \\
\text { proximal dilated loops }\end{array}$ & $\begin{array}{l}\text { Acute intestinal } \\
\text { obstruction }\end{array}$ & $\begin{array}{l}\text { ESR: } 90 \\
\text { AEC: } 70 \text { cells/cumm } \\
\text { Chest X-ray: NAD } \\
\text { Stool examination: NAD } \\
\text { Montoux test: negative }\end{array}$ \\
\hline
\end{tabular}

AEC: absolute eosinophil count: normal range: $40-400$ cells/cumm.

NAD: no abnormality detected.

ESR: $0-20 \mathrm{~mm} / \mathrm{hr}$ in male [normal range].

TABLE 2: Management of individual patient.

\begin{tabular}{lll}
\hline Number & Medical line of management & Surgical management \\
\hline 1 & $\begin{array}{l}\text { Resuscitation, IV antibiotics, albendazole, } \\
\text { Anti-tubercular treatment, analgesic, pantoprazole, } \\
\text { pyridoxine }\end{array}$ & Laparoscopic right hemicolectomy \\
\hline 2 & $\begin{array}{l}\text { Resuscitation, IV antibiotics, albendazole, analgesic, } \\
\text { and prednisolone oral } \\
\text { Pantoprazole }\end{array}$ & $\begin{array}{l}\text { Closure of ileal perforation with biopsy ileo transverse } \\
\text { bypass due to multiple ileal stricture and fibrosed } \\
\text { caecum }\end{array}$ \\
\hline 3 & $\begin{array}{l}\text { Resuscitation, IV antibiotics, albendazole, analgesic, } \\
\text { pantoprazole, and tranexamic acid }\end{array}$ & $\begin{array}{l}\text { Resection and anastomosis of intussuscepted ileal } \\
\text { segment }\end{array}$ \\
\hline & $\begin{array}{l}\text { Resuscitation, IV antibiotics, albendazole, analgesic, } \\
\text { pantoprazole, amlodipine, and SC low molecular } \\
\text { weight heparin }\end{array}$ & Exploratory laparotomy with right hemi colectomy \\
\hline
\end{tabular}

Case 4. A 6-year-old male with history of recurrent subacute intestinal obstruction since 3 months was evaluated with ultrasonography which showed multiple dilated bowel loops with sluggish peristalsis. Patients contrast enhanced CT scan showed thickening in the ileocaecal area with dilated bowel loops. Patient had an elevated ESR and lymphocytosis and also gave history of tuberculosis with intake of antitubercular drugs 35 years back for a one year period. Patient had normal eosinophil count. Exploratory laparotomy and right hemicolectomy was done in view of thickened pulled up illeocaecal junction and dilated proximal loops. Postoperatively patient recovered well. On histopathological examination of specimen eosinophilic infiltration was seen in all layers of intestine (Figures 5 and 6). Detailed clinical history, laboratory, and radiological investigations is summarized in (Tables 1 and 2). 


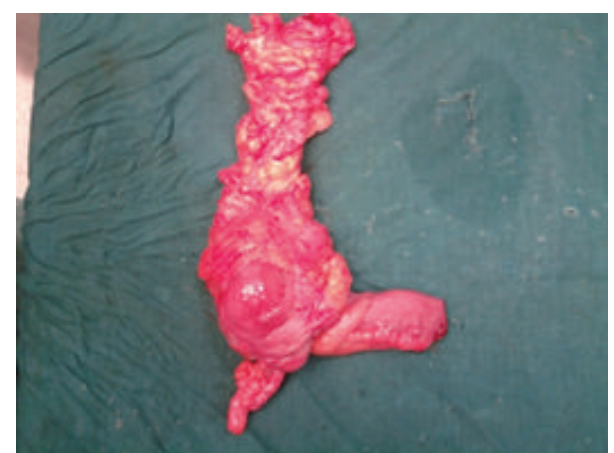

FIgURE 5: Resected specimen of ileum and caecum after right hemicolectomy (Case 4).

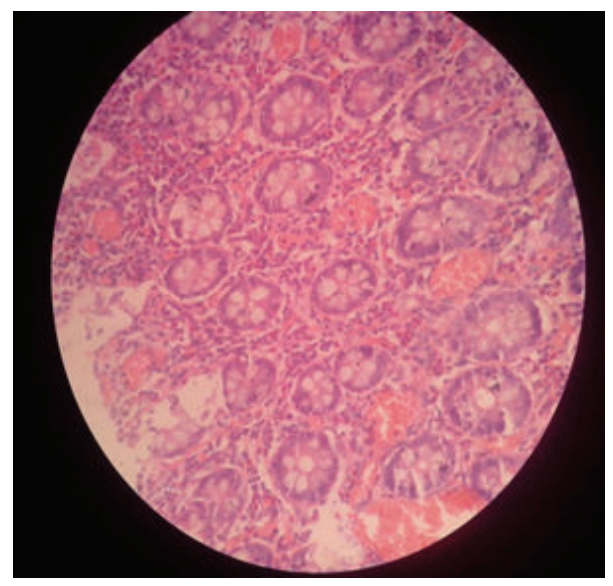

FIGURE 6: Hematoxylin and eosin stain showing eosinophilic infiltrations (more than 100 cells/HPF) in all layers of intestine (Case 4).

\section{Discussion}

Eosinophilic gastrointestinal disease was first described by Kaijser in 1937 [3]. In India, Venkataraman et al. have reported seven cases of EGE over a ten-year period [4]. Diagnosis is one of exclusion and the criteria put forward for the diagnosis are the presence of gastrointestinal (GIT) symptoms, infiltration of the GIT by eosinophils in one or more areas, absence of parasitic infestation, and exclusion of eosinophilic involvement in organs other than the GIT [5]. The diagnosis of EE is made from the presence of gastrointestinal symptoms, peripheral eosinophilia, endoscopic and histological findings, and eosinophilic ascites, with no welldefined causes of eosinophilia on thorough evaluation. In the present case series only two patients had raised peripheral eosinophil count but all had eosinophilic infiltration of $>100$ cells/HPF on histopathological examination. Hence in a suspected case of EE a colonoscopic biopsy at multiple sites showing eosinophilic infiltration can be one of the diagnostic tools in confirming the disease.

In our case series of four patients two of them had ileocaecal mass with recurrent subacute intestinal obstruction with past history of intake of antitubercular drugs for 9 months. On histopathological examination both of them proved to have eosinophilic enterocolitis. Thus it is a clinical dilemma to differentiate between these two conditions. The other two patients presented as acute abdomen with perforation and intussusception. All four patients were treated surgically. Postoperatively they recovered well with no symptoms on one year follow-up.

Various case reports have been reported where eosinophilic enteritis mimics tuberculosis and ulcerative colitis. In the present case series also out of four patients two of them had a history of abdominal tuberculosis in the past and treatment for the same was taken. Lange et al. proposed rifampicin as a cause of eosinophilic colitis as its side effect [6]. In the present case series it was an enigma to distinguish whether the patients were wrongly diagnosed cases of tuberculosis or were they actual case of eosinophilic enteritis or patient had eosinophilic enteritis as a side effect secondary to the consumption of rifampicin. Both of these patients did not have a proven biopsy suggestive of tuberculosis before starting treatment. According to history they were on anti-tubercular drugs only based on clinical suspicion and CT picture. Drugs reported to cause colonic eosinophilia include nonsteroidal anti-inflammatories, tacrolimus, carbamazepine, rifampicin, sulphasalazine, and naproxen. None of the patients in the case series had any h/o allergic rhinitis or atopy or food allergy. Thus it is essential to conduct colonoscopic biopsy to differentiate between eosinophilic enterocolitis and tuberculosis. Biopsy has to be taken at multiple sites as the disease has tendency to affect as skip lesions.

Eosinophilic enterocolitis also presents as a mass lesion which can be confused with neoplasm. In the third case patient had a lump on CT scan with target lesion which was suspected as malignancy causing a leading point for intussusception but was surprisingly proved as EE. Thus eosinophilic gastrointestinal disorders even though rare have to be kept as differential diagnosis as it is a benign and an easily treatable entity.

Supportive treatment with pharmacotherapy, mainly oral glucocorticosteroids, is indicated for those with obstructive symptoms. Patients with mucosal layer involvement may benefit from anti-inflammatory medications (e.g., oral glucocorticoids) and/or diet elimination therapy, particularly if they report a history of food intolerance or allergy. Drugs, such as montelukast, ketotifen, and mycophenolate mofetil, and alternative Chinese medicines have been advocated but are generally not successful. Recurrence is common even after surgical resection.

\section{Conclusion}

Eosinophilic enteritis even though a rare disorder has a varied spectrum of presentation which is easily misinterpreted as neoplasm, tuberculosis, and inflammatory bowel disease. Since it can be easily treated medically and surgically it has to be diagnosed with certainty. In developing countries, as incidence of Tuberculosis is high it is common to wrongly diagnose case of eosinophilic enteritis as tuberculosis. Thus a strong clinical suspicion and awareness of this clinical entity are essential among surgical fraternity. 


\section{Conflict of Interests}

The authors declare that there are no financial interests or any conflict of interests.

\section{References}

[1] A. A. Alfadda, M. A. Storr, and E. A. Shaffer, "Eosinophilic colitis: epidemiology, clinical features, and current management," Therapeutic Advances in Gastroenterology, vol. 4, no. 5, pp. 301309, 2011.

[2] G.-Y. Ong, C.-C. Hsu, C.-S. Changchien, S.-N. Lu, and S.-C. Huang, "Eosinophilic gastroenteritis involving the distal small intestine and proximal colon," Chang Gung Medical Journal, vol. 25, no. 1, pp. 56-61, 2002.

[3] R. Kaijser, "Zurkenntnis der allergisschen des verdauungskabals vonstandpunkt des chiruugan aus," Archiv fur klinische Chirurgie, vol. 36, p. 188, 1937.

[4] S. Venkataraman, B. S. Ramakrishna, M. Mathan et al., "Eosinophilic gastroenteritis-an Indian experience," Indian Journal of Gastroenterology, vol. 17, no. 4, pp. 148-149, 1998.

[5] N. J. Talley, R. G. Shorter, S. F. Phillips, and A. R. Zinsmeister, "Eosinophilic gastroenteritis: a clinicopathological study of patients with disease of the mucosa, muscle layer, and subserosal tissues," Gut, vol. 31, no. 1, pp. 54-58, 1992.

[6] P. Lange, H. Oun, S. Fuller, and J. H. Turney, "Eosinophilic colitis due to rifampicin," The Lancet, vol. 344, no. 8932, pp. 1296-1297, 1994. 


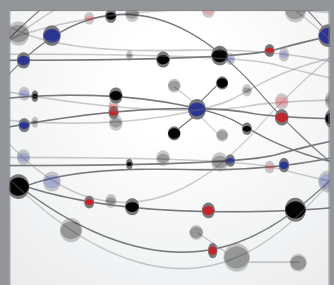

The Scientific World Journal
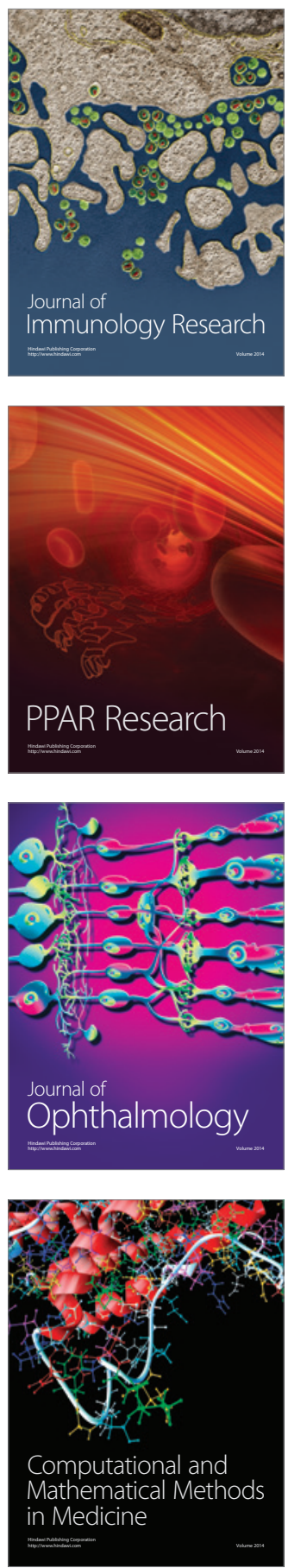

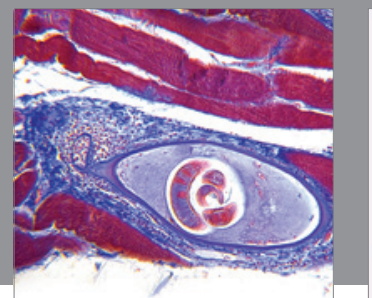

Gastroenterology

Research and Practice
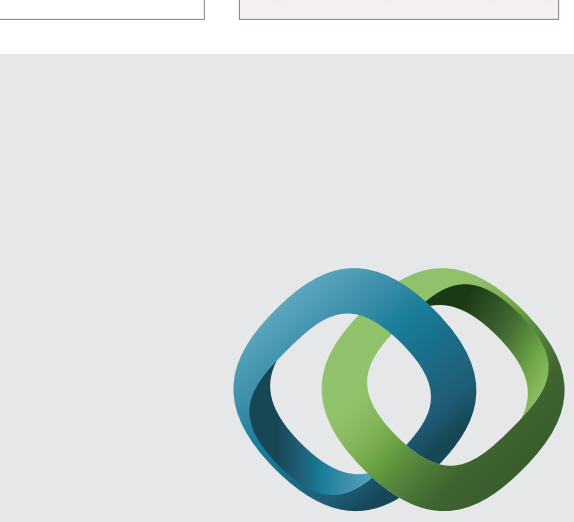

\section{Hindawi}

Submit your manuscripts at

http://www.hindawi.com
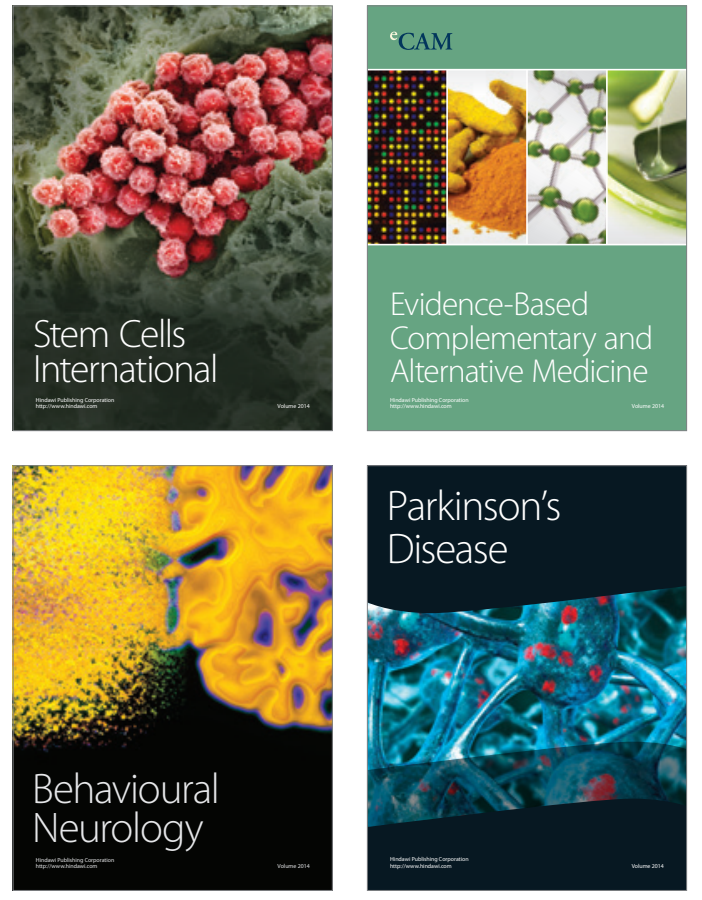
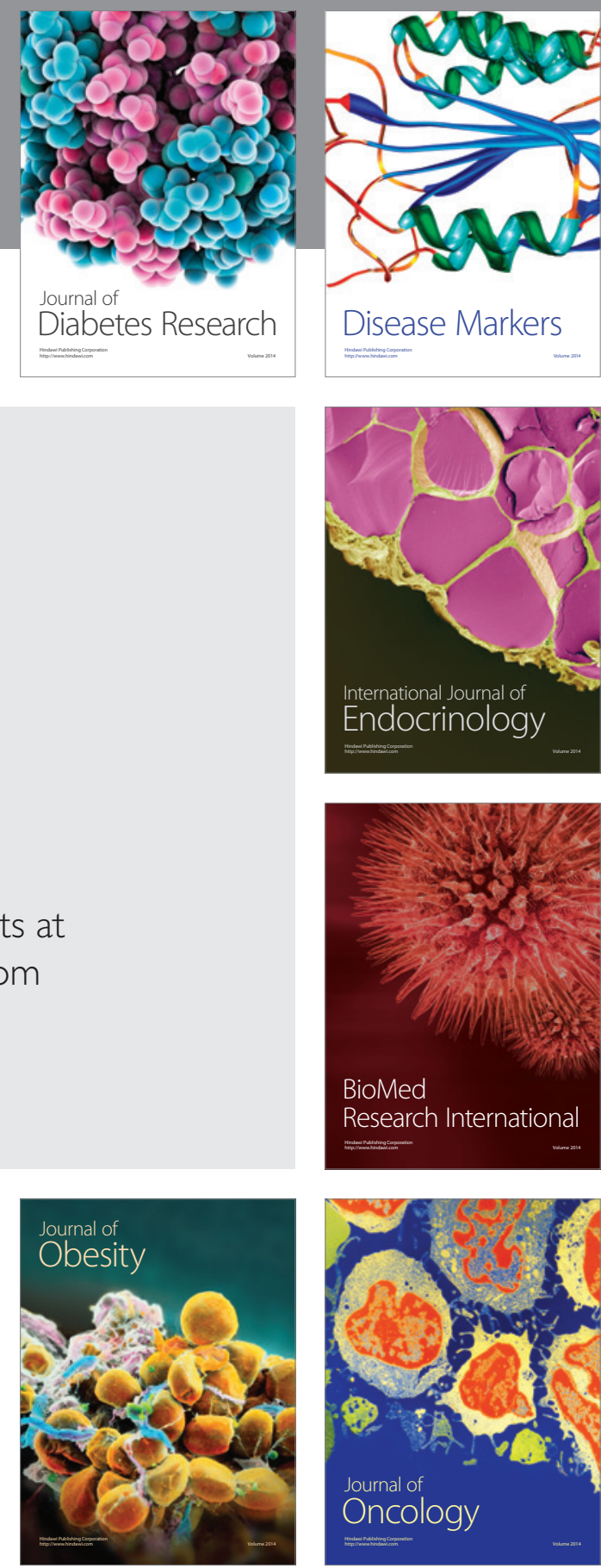

Disease Markers
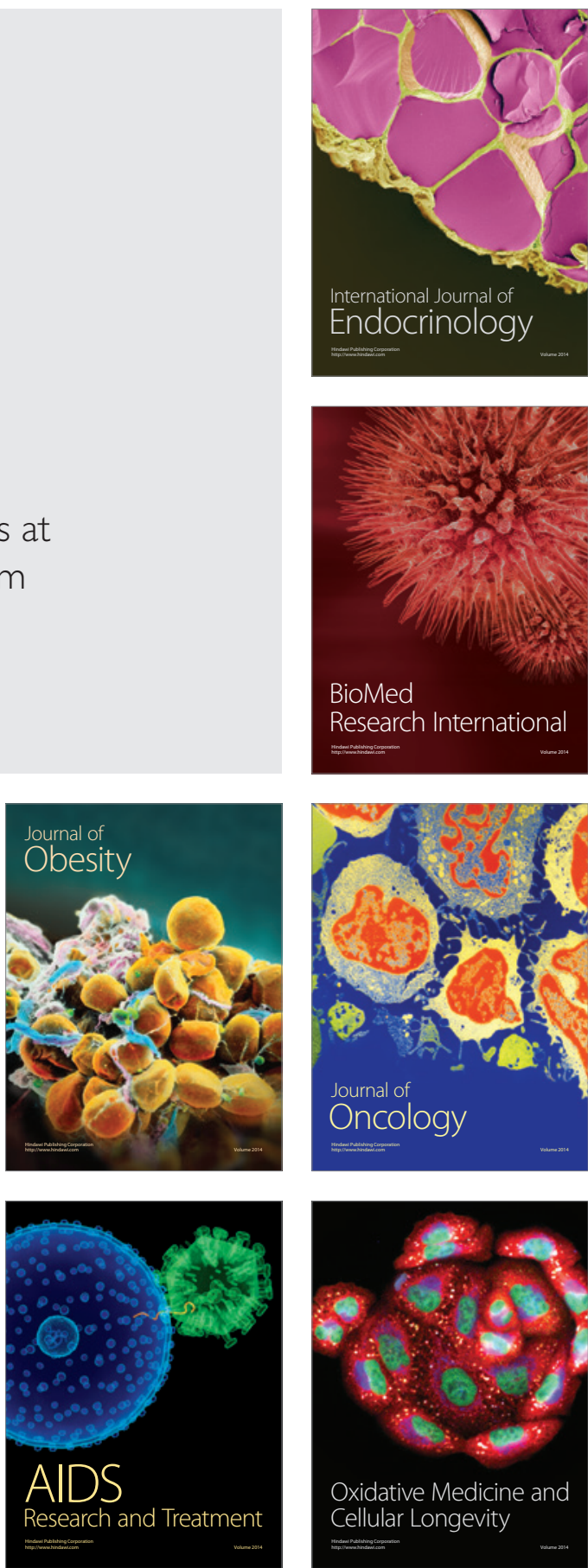